\title{
Upaya Meningkatkan Kemampuan Berpikir Kritis Siswa dan Sikap Demokratis Siswa pada Mata Pelajaran PKn melalui Penerapan Model Pembelajaran Kooperatif Tipe Group Investigation (GI)
}

\author{
I Made Pater \\ SMK Negeri 3 Singaraja \\ e-mail: patermd21@gmail.com
}

\begin{abstract}
Abstrak
Penelitian ini bertujuan untuk meningkatkan kemampuan berpikir kritis siswa dan sikap demokratis Siswa pada mata pelajaran PKn melalui penerapan model pembelajaran kooperatif tipe Group Investigation (GI) pada Siswa Kelas X TITL 1 SMK Negeri 3 Singaraja. Jenis penelitian ini tergolong penelitian tindakan kelas (PTK). Penelitian dilakukan sebanyak 2 siklus dengan rancangan siklus terdiri dari tahap rencana tindakan, pelaksanaan tindakan, evaluasi/observasi dan refleksi. Subjek penelitian ini adalah siswa kelas X TITL 1 SMK Negeri 3 Singaraja tahun pelajaran 2018/2019 dengan jumlah siswa 35 orang. Data dikumpulkan melalui observasi, tes, angket dan dokumentasi. Data yang didapat selanjutnya dianalisis dengan teknik deskriftif kualitatif dan deskriftif kuantitatif. Hasil analisis menunjukkan bahwa telah terjadi peningkatan kemampuan berpikir kritis kelas X TITL 1 SMK Negeri 3 Singaraja tahun pelajaran 2018/2019 dan terjadi peningkatan sikap demokratis siswa yang berada pada kategori tinggi.
\end{abstract}

Kata Kunci : Gl (Group Investigation), Kemampuan Berpikir Kritis, Sikap Demokratis

\begin{abstract}
This study was aimsed at to improving the critical thinking ability and democratic attitude of the Students in Civics subjects through the application of cooperative learning models of the type of Group Investigation (GI) to Class X Students of TITL 1 of SMK Negeri 3 Singaraja. This type of research was classroom action research (PTK). The research was conducted in 2 cycles with cycle design consisting of planing stage, acting implementating, evaluating / observating and reflecting. The subjects of this study were the students of grade X TITL 1 SMK Negeri 3Singaraja year of 2018/2019 with the number of students were 20 people. Data were collected through observation, tests, questionnaires and documentation. The data were then analyzed using qualitative and quantitative descriptive techniques. The result of this study showed that the implementation of Gl learning model to the students grade X TITL 1 SMK Negeri 3 Singaraja in the years of 2018/2019 could improve students critical thingking and demo cratic attitude in the high category.
\end{abstract}

Keywords: GI (Group Investigation), Critical Thinking Ability, Democratic Attitude 


\section{Pendahuluan}

Upaya melakukan perbaikan di bidang pendidikan menjadi tanggung jawab semua pihak, salah satunya adalah guru. Hamalik (Dita 1991: 44) yang mengatakan bahwa "Guru bertanggung jawab melaksanakan kegiatan pendidikan di sekolah dalam arti memberikan bimbingan dan pengajaran kepada para siswa". Guru harus dapat melakukan suatu inovasi yang menyangkut tugasnya sebagai pendidik yang berkaitan dengan tugas mengajar siswa. Inovasi-inovasi yang dilakukan guru dalam tugasnya sebagai pendidik diharapkan mampu meningkatkan prestasi belajar siswa. Mengingat bahwa guru juga memberi pengaruh terhadap prestasi belajar siswa. Sebagaimana dikemukakan oleh Hamzah B. Uno (Dita 2008:17) bahwa "Seorang guru sangat berpengaruh terhadap hasil belajar yang dapat ditunjukkan oleh peserta didiknya".

Menurut Undang-undang Republik Indonesia nomor 20 tahun 2003 tentang Sistem Pendidikan Nasional, pendidikan adalah usaha sadar dan terencana untuk mewujudkan suasana belajar dan proses pembelajaran agar peserta didik secara aktif mengembangkan potensi dirinya untuk memiliki kekuatan spiritual keagamaan, pengendalian diri, kepribadian, kecerdasan, akhlak mulia, serta keterampilan yang diperlukan dirinya, masyarakat, bangsa dan negara. Pendidikan Kewarganegaraan (PKn) merupakan salah satu mata pelajaran yang dapat membentuk diri yang beragam dari segi agama, sosiokultural, bahasa, usia, untuk menjadi warga negara yang cerdas, terampil dan berkarakter yang dilandasi oleh UUD 1945. Hal ini sesuai dengan yang dikemukakan oleh Depdiknas (2005: 34) bahwa: 'Pendidikan Kewarganegaraan merupakan mata pelajaran yang secara umum bertujuan untuk mengembangkan potensi individu warga negara Indonesia, sehingga memiliki wawasan, sikap, dan keterampilan kewarganegaraan yang memadai dan memungkinkan untuk berpartisipasi secara cerdas dan bertanggung jawab dalam berbagai kehidupan bermasyarakat, berbangsa dan bernegara". Melalui pelajaran Pendidikan Kewarganegaraan (PKn) diharapkan siswa mampu berpikir secara kritis, rasional, kreatif dalam menanggapi situasi, berpartisipasi secara cerdas dan bertanggung jawab, serta bertindak secara sadar dalam kegiatan bermasyarakat, berbangsa, dan bernegara.

Sekolah merupakan lembaga pendidikan yang menampung peserta didik dan membina siswa agar mereka memiliki kemampuan, kecerdasan, dan keterampilan. Proses pendidikan memerlukan pembinaan secara terkoordinasi dan terarah yang diharapkan siswa dapat mencapai prestasi belajar yang maksimal sehingga tercapainya tujuan pendidikan. Sekolah Menengah Kejuruan (SMK) merupakan lembaga pendidikan menengah yang mempersiapkan peserta didik untuk terampil dalam bidang tertentu. SMK diharapkan mampu menghasilkan lulusan yang dapat bekerja sebagai tenaga yang produktif, memiliki kemampuan, keterampilan, dan siap kerja sehingga tidak hanya siap mengisi lapangan kerja tetapi juga mampu menciptakan lapangan kerja.

Namun kenyataannya mata pelajaran PKn bukan mata pelajaran yang dianggap favorit, baik dimata siswa, guru, kepala sekolah ataupun masyarakat luas, karena kecenderungan menunjukkan bahwa mata pelajaran PKn dianggap mata pelajaran yang lunak, tidak menyenangkan dan membosankan serta di lapangan menunjukkan bahwa sebagian guru PKn dalam Proses Belajar Mengajar (PBM) terbatas pada penggunaan model pembelajaran. (Ita Damayanti:2017)

Kenyataan yang terjadi di lapangan saat ini, guru-guru dalam proses pembelajaran khususnya mata pelajaran PKn di Sekolah Menengah Atas/Kejuruan masih menggunakan model pembelajaran konvensional yang lebih menekankan pada metode ceramah. Sesuai dengan pendapat yang disampaikan oleh Rasana (2009), model pembelajaran konvensional memiliki kelemahan yaitu: (1) guru menggunakan metode ceramah sehingga guru berperan penuh sebagai sumber informasi (teacher centered), (2) siswa merupakan penerima informasi secara pasif dari guru, (3) menyebabkan peserta didik menjadi pasif, (4) pembelajaran sangat abstrak dan teoritis, (4) guru adalah penentu jalannya proses pembelajaran, (5) interaksi diantara siswa kurang, (6) kegiatan belajar mengajar lebih menekankan pada hasil dari pada proses. Hal tersebut terjadi pula di Sekolah Menengah Kejuruan Negeri 3 Singaraja. (Ita Damayanti:2017). Menurut Sumertha (2019) dalam penyelenggaraan pembelajaran seorang pendidik harus bisa memilih model mengajar yang sesuai untuk suatu materi tertentu dan menggunakan interaksi belajar mengajar yang berdaya guna untuk mencapai tujuan pembelajaran. Oleh karena itu dalam mengajar, pendidik harus mampu memilih model mengajar yang cocok untuk masing-masing materi pembelajaran, yang harus disesuaikan dengan tujuan pembelajaran. Dengan memilih model pembelajaran yang tepat untuk suatu 
materi, akan membawa hasil yang baik dan suasana menyenangkan sehingga siswa mudah memahami materi yang dipelajari.

Peneliti memfokuskan perhatian pada kelas X TITL 1. Permasalahan yang ditemukan adalah bahwa di kelas X TITL 1 SMK Negeri 3 Singaraja terdapat permasalahan kurangnya kemampuan untuk memberikan contoh kasus di dalam masyarakat, siswa kurang bergairah dalam pelajaran, malu bertanya dan mengungkapkan pendapat, bersifat individu satu sama lain dan kurang memiliki sikap positif terutama sikap demokratis dalam pembelajaran, karena kurangnya kemampuan guru dalam mengelola kelas. Sesuai dengan hasil observasi di kelas $X$ TITL 1 pada saat proses pembelajaran, guru juga sudah menerapkan salah satu model pembelajaran kooperatif yang ada namun masih kurang baik, hal tersebut dapat dilihat dari masih banyaknya siswa yang hanya terpaku terhadap apa yang disampaikan guru dan tidak mau memberikan pendapat atau pertanyaan saat proses pembelajaran di kelas berlangsung. Selain itu pada saat salah satu kelompok belajar siswa melakukan persentasi mengenai materi yang dipelajari, siswa yang lain tidak mau mendengarkan apa yang dipersentasikan oleh temannya dan memilih bercanda, karena siswa menganggap proses pembelajaran membosankan.

Selain masalah pengelolaan kelas yang kurang baik, ada juga penyebab lain rendahnya kemapuan berpikir kritis dan sikap demokratis siswa di kelas X TITL 1 yaitu: 1) kurangnya pemilihan dan penerapan model pembelajaran yang tepat dan sesuai dengan keadaan kelas $X$ TITL 1, guru sudah menerapkan model pembelajaran yang kooperatif, namun masih kurang maksimal penerapannya, sehingga membuat siswa yang banyak merasa bosan, mengantuk dan ribut membahas hal yang lain - lain dalam mengikuti proses pembelajaran. Sehingga pemilihan model pembelajaran yang tepat itu sangatlah penting agar dapat meningkatkan kemampuan berpikir kritis siswa dan membuat siswa semangat dalam mengikuti pembelajaran, 2) masih kurangnya penerapan strategi pembelajaran saat guru mengajar, hal tersebut dapat dilihat dari kurangnya perpanduan kegiatan pembelajaran yang tidak sesuai dengan perencanaan pembelajaran yang telah dibuat dan guru hanya menerapkan strategi pembelajaran yang telah dibuat dan guru hanya menerapkan strategi pembelajaran yang sangat umum, yaitu guru hanya menyampaikan materi di depan kelas saja, memberikan tugas pada siswa dan mempersentasikannya, dan 3) selain itu kurangnya sumber belajar siswa pada saat pembelajaran dimana siswa hanya terpaku pada satu sumber belajar yaitu hanya bersumber dari buku siswa dan pegangan guru, (Suariana,2017).

Berdasarkan uraian di atas peneliti menganggap bahwa model pembelajaran kooperatif dapat diterapkan dalam penelitian ini terutama tipe Group Investigation (GI). Menurut Harahap (2017) Model pembelajaran kooperatif tipe Gl adalah sebuah model yang tidak mengharuskan siswa menghafal fakta dan rumus-rumus tetapi sebuah model yang membimbing para siswa mengidentifikasi topik, merencanakan investigasi di dalam kelompok, melaksanakan penyelidikan, melaporkan, dan mempresentasikan hasil penyelidikannya. Menurut Akly (2015) model pembelajaran kooperatif tipe Group Investigation (Gl) adalah model pembelajaran yang melibatkan siswa sejak perencanaan, baik dalam menentukan topik maupun cara untuk mempelajari melalui investigasi. Model pembelajaran ini menuntut para siswa untuk memiliki kemampuan yang baik dalam keterampilan proses kelompok. Menurut Arisinta (2017) model pembelajaran kooperatif tipe Group Investigation dapat memberikan kesempatan bagi siswa untuk berpartisipasi dalam memecahkan masalah dengan benda konkret yang dikaji antar individu dalam suatu kelompok. Selain itu model Gl lebih menekankan pada proses pencarian pengetahuan dari pada transfer pengetahuan. Menurut Artini (2015) Model pembelajaran kooperatif tipe Group Investigation dipilih karena dapat memberikan kesempatan bagi siswa untuk berpartisipasi dalam memecahkan masalah yang dikaji antar individu dalam kelompoknya untuk memperoleh kesepakatan dalam penyelesaian permasalahan yang diberikan oleh guru. Dengan demikian masing-masing siswa akan terlibat langsung dalam proses tersebut. Menurut Eggen \& Kauchak (Maimunah, 2005:21) Gl strategi belajar kooperatif yang menempatkan siswa ke dalam kelompok untuk melakukan investigasi terhadap suatu topik. Dari pernyataan tersebut dapat disimpulkan bahwa model Gl mempunyai fokus utama untuk melakukan investigasi terhadap suatu topik atau objek khusus. Gl mengambil model dari masyarakat, terutama mengenai mekanisme sosial yang ada pada masyarakat yang biasa dilakukan melalui kesepakatan bersama. Melalui kesepakatan inilah siswa mempelajari pengetahuan dan mereka melibatkan diri dalam pemecahan masalah sosial. Group Investigation merupakan salah satu model pembelajaran kooperatif yang memiliki 6 sintaks dalam kegiatan pembelajarannya. keenam sintaks tersebut adalah menentukan topik pembelajaran, merencanakan kegiatan investigasi, melakukan kegiatan investigasi, menyiapkan laporan akhir, mempresentasikan 
laporan akhir, dan evaluasi. Penelitian yang dilakukan oleh Pitoyo, dkk. (2014) menunjukkan hasil bahwa siswa yang belajar dengan model pembelajaran Group Investigation memiliki kemampuan kognitif yang lebih baik. Selain itu, penelitian yang dilakukan oleh Adora (2014) menunjukkan hasil bahwa model Group Investigation dapat membangun sikap kepemimpinan dan keterampilan sosial siswa, serta melibatkan siswa dalam kegiatan pembelajaran yang dapat membangun kebiasaan bekerja sama.

Berdasarkan uraian di atas, peneliti mencoba menerapkan model pembelajaran kooperatif Tipe Group Investigation (GI) dengan melaksanakan penelitian tindakan kelas yang berjudul "Upaya Meningkatkan Kemampuan Berpikir Kritis Siswa dan Sikap Demokratis Siswa pada Mata Pelajaran PKn melalui Penerapan Model Pembelajaran Kooperatif Tipe Group Investigation (GI) pada Siswa Kelas X TITL 1 SMK Negeri 3 Singaraja".

\section{Metode}

Penelitian ini menggunakan rancangan Penelitian Tindakan Kelas (PTK). Dalam penelitian ini guru juga sekaligus bertindak sebagai peneliti. Model rancangan penelitian ini mengacu pada model yang dikemukakan oleh Kemmis dan Tagart (1998) dengan dua siklus. Rancangan penelitian tindakan kelas yang digunakan dalam melaksanakan penelitian ini adalah rancangan tindakan kelas model Kemmis (1982) yang terdiri dari empat tahapan yaitu: (1) Tahap Perencanaan, (2) Tahap Pelaksanaan, (3) Tahap Observasi dan (4) Tahap Refleksi.

\section{1) Tahap Perencanaan}

Kegiatan yang dilakukan dalam perencanaan tindakan adalah sebagai berikut: (1) Penyamaan persepsi dengan guru mengenai penerapan model pembelajaran Gl (Group Investigation) meningkatkan berpikir kritis PKn dan Sikap Demokratis. (2) Menentukan materi materi yang dibahas dalam penelitian, sessuai dengansilbus yang ada. (3) Menyiapkan alat dan bahan pembelajaran antara lain: menyiapkan rencana pelaksanaan pembelajaran (RPP), menyiapkan lembar kerja siswa (LKS) dan menyiapkan alat, bahan, media yang digunakan dalam kegiatan pembelajaran. (4) Membentuk kelompok heterogen, dengan anggota masing masing berjumlah 5 orang. (5) Menyiapkan tes untuk tes akhir siklus kemampuan berpikir kritis siswa pada setiap siklus sesuai dengan materi yang dikaji. Dan tes yang digunakan berupa soal uraian. (6) Menyiapkan pedoman observasi (non-tes) terkait dengan penilaian kemampuan berpikir kritis ranah psikomotorik (kegiatan diskusi kelompok). (7) Menyiapkan kuisioner untuk mengetahui respon siswa terhadap sikap demokratis siswa.

\section{2) Tahap Pelaksanaan}

Pelaksanaan tindakan sesuai dengan tahap dari model pembelajaran GI (Group Investigation) untik meningkatkan kemampuan berpikir kritis siswa dan Sikap Demokratis siswa. Tindakan yang dilakukan berdasarkan pada RPP (Rencana Pelaksanaan Pembelajaran). Setiap tindakan siklus dilaksanakan dalam 3 kali pertemuan (2 kali pertemuan pembelajaran dan 1 kali tes akhir siklus).

\section{3) Observasi/Evaluasi}

Observasi dilaksanakan dari awal sampai akhir pembelajaran, hasil observasi digunakan sebagai bahan refleksi. Pada saat pembelajaran dilaksanakan juga observasi terkait dengan penilaian kemampuan berpikir kritis ranah psikomotorik (kegiatan diskusi kelompok). Evaluasi berupa tes dilakukan unuk mengetahui dampak model pembelajaran GI (Group Investigation) terhadap kemampuan berpikir kritis PKn.

\section{4) Tahap Refleksi}

Refleksi yang dilakukan pada awal kegiatan diberikan pada upaya penyempurnaan rancangan pembelajaran yang akan dilaksanakan dalam satu siklus menjadi lebih efektif. Refleksi diakhir siklus bertujuan untuk memperoleh kesepakatan tindakan selanjutnya sehingga pelaksanaan tindakan selanjutnya menjadi lebih baik. Pelaksanaan refleksi ini berdasarkan data hasil observasi kegiatan pembelajaran dalam bentuk penerapan model diskusi kelompok dan juga kegiatan evaluasi pada akhir siklus dalam bentuk tes. Langkah - langkah yang dilakukan pada siklus I akan dilanjutkan pada siklus II, dengan materi yang tetap disesuaikan dengan silabus. 
Lokasi atau tempat diadakannya penelitian ini adalah di SMK Negeri 3 Singaraja. Subjek dalam penelitian ini adalah siswa kelas X TITL 1 SMK Negeri 3 Singaraja, yang berjumlah 35 orang.

Untuk mengumpulkan data penelitian, maka digunakan metode dan instrumen penelitian yang disesuaikan dengan variabel yang ingin diukur. Pengumpulan data dilakukan dengan menggunakan metode Observasi (non tes), tes, kuisioner dan dokumentasi yang bertujuan untuk memperoleh data yang diharapkan. Data yang dikumpulkan dalam penelitian ini yaitu data kemampuan berpikir kritis dan sikap demokratis siswa pada mata pelajaran PKn kelas $X$ TITL 1 SMK Negeri 3 Singaraja setelah menerapkan model pembelajaran kooperatif tipe Group Investigation (Gl). Analisis data yang digunakan dalam penelitian tindakan kelas ini menggunakan analisis data deskriftif kualitatif dan deskriftif kuantitatif (Iskandar, 2008:4).

Indikator keberhasilan yang digunakan untuk mengukur keberhasilan penelitian tindakan kelas ini yakni: (1) Penelitian tindakan kelas untuk mengukur Kemampuan Berpikir Kritis siswa ini dikatakan berhasil apabila kemampuan belajar siswa berada pada kategori baik, (2) Penelitian ini dikatakan berhasil apabila hasil sikap demokratis berada pada kategori tinggi.

\section{Hasil dan Pembahasan}

Penelitian ini merupakan penelitian tindakan kelas yang dilaksanakan di kelas X TITL 1 SMK Negeri 3 Singaraja tahun pelajaran 2018/2019. Penelitian ini dilaksanakan dari 8 April sampai 13 Mei 2019. Dalam setiap proses pembelajaran dibentuk menjadi 7 kelompok belajar dengan setiap kelompok terdiri dari 5 orang siswa. Penelitian tindakan kelas ini dilaksanakan sebanyak 2 kali siklus. Masing - masing siklus dibagi menjadi 3 kali pertemuan yaitu 2 kali pertemuan pemberian materi pembelajaran dan 1 kali pertemuan pemberian kuisioner dan tes akhir siklus. Penilaian terhadap kemampuan berpikir kritis siswa menggunakan metode non tes dan tes. Dan untuk penilaian sikap demokratis siswa menggunakan angket/kuisioner.

Sesuai dengan rancangan siklus I, rencana pembelajaran dilaksanakan 3 kali pertemuan, dimana terdiri dari 2 kali tatap muka untuk membahas materi dan 1 kali memberikan kuisioner dan tes akhir siklus I. dengan materi pokok dan kompetensi dasar yang telah diberikan. Alokasi waktu dalam satu kali pertemuan selama 2 jam pelajaran atau 80 menit, dalam seminggu terdapat dua kali pertemuan yaitu pada hari selasa jam $4-5$ (09.45 - 11.05 wita) dan jumat jam 1 - 2 (07.30 - 09.15 wita). Untuk mencapai tujuan pembelajaran tersebut, pembelajaran dilakukan dengan beberapa langkah yaitu sebagai berikut: Kegiatan diawal pembelajaran peneliti memasuki kelas yang diteliti, selanjutnya (1) langkah pertama yaitu mengidentifikasikan topik dan mengatur murid ke dalam kelompok. Para siswa meneliti beberapa sumber,mengusulkan sejumlah topik, para siswa bergabung dengan kelompoknya untuk mempelajari topik yang telah mereka pilih. (2) Langkah kedua yaitu merencanakan tugas yang akan dipelajari. Direncanakan secara bersama - sama oleh para siswa di dalam kelompoknya masing - masing meliputi: Apa yang kita pelajari, bagaimana kita mempelajarinya dan untuk apa topik itu di investigasi. Kemudian peneliti membagikan lembaran permasalahan atau kasus yang akan didiskusikan atau masing - masing kelompok melakukan investigasi terhadap kasus yang diberikan. (3) Langkah ketiga yaitu melaksanakan investigasi, para siswa mengumpulkan informasi, menganalisis data, dan membuat kesimpulan. Tiap anggota kelompok berkontribusi untuk usaha - usaha yang dilakukan kelompoknya dan para siswa saling bertukar, berdiskusi, mengklarifikasi, dan mensintesis semua gagasan. (4) Langkah empat yaitu menyiapkan laporan akhir, anggota kelompok menentukan pesan - pesan esensial dan proyek mereka. Anggota kelompok merencanakan apa yang akan mereka laporkan, dan bagaimana mereka akan membuat presentasi mereka. (5) Langkah lima yaitu mempresentasikan laporan akhir, presentasi yang dibuat untuk seluruh kelas dalam berbagai macam bentuk. Bagian presentasi tersebut harus dapat melibatkan pendengar kelompok lain secara aktif. (6) yaitu evaluasi, para siswa saling memberikan umpan balik mengenai topik tersebut, mengenai tugas yang telah mereka kerjakan, mengenai keefektifan pengalaman pengalaman mereka. Guru dan murid berkolaborasi dalam mengevaluasi pembelajaran siswa.

Pertemuan kedua siklus I langkah - langkah pembelajaran sama dengan pertemuan pertama, tetapi indikator dan tujuan pembelajaran berbeda dengan pertemuan pertama. Dimana pada pertemuan kedua ini KD yang diberikan sama dengan pertemuan pertama. 
Hasil Penelitian Siklus I

Data tentang kemampuan berpikir kritis siswa, melaui tes akhir siklus nilai terendah diperoleh siswa dengan nilai 68 dan nilai tertinggi diperoleh siswa dengan nilai 78,6 dari jumlah siswa kelas X SMK Negeri 3 Singaraja sebanyak 35 orang. Sedangkan rata - rata kemampuan berpikir kritis siswa berada pada skor 71,19.

Dengan persentase kemampuan berpikir kritis siswa dengan menggunakan model Pembelajaran GI (Group Investigation) dalam mata pelajaran PKn di kelas X TITL 1 SMK Negeri 3 Singaraja Tahun Pelajaran 2018/2019 Siklus I berada pada presentase $71,19 \%$. Dengan melihat pada hasil persentase kemampuan berpikir kritis siswa dan penggolongan nilai kemampuan berpikir kritis siswa diketahui bahwa kemampuan berpikir kritis siswa pada siklus I berada pada kriteria cukup dengan 35 orang siswa masih pada kriteria cukup dengan interval 65-79. Penentuan keberhasilan kemampuan berpikir kritis siswa yang telah ditentukan sebelumnya yakni berada pada kategori "baik" pada interval 80 - 89 sehingga bisa dikatakan pelaksanaan tindakan siklus I belum berhasil dan dilanjutkan pada siklus II.

Data sikap demokratis siswa pada siklus I disajikan pada lampiran berdasarkan data tersebut bahwa jumlah skor keseluruhan sikap demokratis siswa kelas X TITL 1 SMK Negeri 3 Singaraja pertemuan I dan pertemuan II pada siklus I adalah 1.609 dengan rata - rata 80,45 dan Standar deviasi 2.8. Berdasarkan pedoman penggolongan sikap demokratis siswa yang telah diterapkan, sikap demokratis siswa kelas X SMK Negeri 3 Singaraja berada pada kategori sedang. Berdasarkan data yang diperoleh sampai akhir siklus I, dapat direfleksikan hal sebagai berikut:

1. Masih ada beberapa siswa yang kurang tertarik untuk mengikuti pelajaran dapat dilihat dari kebanyakan siswa yang mengobrol dibandingkan siswa yang mengikuti pelajaran disini akan menganggu siswa yang mengikuti pelajaran sehingga proses pembelajaran tidak kondusif.

2. Siswa kesulitan dalam menyatukan pendapat dalam investigasi atau diskusi yang menyebabkan siswa belum bisa menyelesaikan tugas diskusi sesuai dengan waktu yang ditentukan. Hal tersebut disebabkan karena siswa dalam proses pembelajaran lebih banyak waktunya untuk mengobrol dibandingkan dengan berdiskusi atau melakukan investigasi terhadap kasus yang diberikan, jadi waktu yang diberikan terbuang dengan sia - sia sehingga proses investigasi atau diskusi kurang berjalan dengan baik.

3. Siswa masih malu dan takut menyampaikan pendapat pada saat pembelajaran berlangsung hal ini disebabkan karena mereka masih takut pendapat yang mereka sampaikan salah.

4. Penyampaian hasil investigasi atau diskusi sering menyimpang dari materi atau pembahasan materi diskusi, sehingga menyita waktu terlalu banyak yang mengakibatkan kelompok lain kekurangan waktu dalam mempresentasikan hasil kerja kelompoknya.

Untuk dapat memperbaiki kekurangan dan mampu mempertahankan keberhasilan yang sudah dicapai pada siklus I, maka pada siklus II dapat dilakukan perbaikan dengan menciptakan proses pembelajaran yang menyenangkan yaitu dengan cara memberikan semangat yang bersifat mendukung siswa agar lebih aktif dalam melakukan pembelajaran.

Hasil Penelitian Siklus II

Data tentang kemampuan berpikir kritis siswa, melaui tes akhir siklus kemampuan berpikir kritis siswa siklus II yang dilaksanakan sebanyak 3 kali pertemuan dengan 2 kali pertemuan pembahasan materi 1 kali pertemuan tes akhir siklus II diketahui dari tabel diatas. Adapun hasil dari kemampuan berpikir kritis siswa, nilai terendah diperoleh siswa dengan nilai 81 dan nilai tertinggi diperoleh siswa dengan nilai 90,4 dari jumlah siswa kelas X TITL 1 SMK Negeri 3 Singaraja sebanyak 35 orang. Sedangkan rata - rata kemampuan berpikir kritis siswa berada pada skor 85,36 .

Dengan persentase kemampuan berpikir kritis siswa dengan menggunakan model Pembelajaran GI (Group Investigation) dalam mata pelajaran PKn di kelas X TITL 1 SMK Negeri 3 Singaraja Tahun Pelajaran 2018/2019 Siklus II berada pada presentase 85,36\%. Dengan melihat pada hasil persentase kemampuan berpikir kritis siswa dan penggolongan nilai kemampuan berpikir kritis siswa diketahui bahwa kemampuan berpikir kritis siswa pada siklus II berada pada kriteria baik sebanyak 32 siswa dan sebanyak 3 orang siswa berada pada kriteria sangat baik. Penentuan keberhasilan kemampuan berpikir kritis siswa yang telah ditentukan sebelumnya yakni berada pada kategori "baik" pada interval 80 - 89 sehingga bisa dikatakan pelaksanaan tindakan siklus II bisa dikatakan berhasil.

Data sikap demokratis siswa pada siklus II disajikan pada lampiran berdasarkan data tersebut bahwa jumlah skor keseluruhan sikap demokratis siswa kelas X TITL 1 SMK Negeri 3 Singaraja pertemuan I dan pertemuan II pada siklus II adalah 1.853 dengan rata - rata 92,65 
dan Standar deviasi 4,5. Berdasarkan pedoman penggolongan sikap demokratis siswa yang telah diterapkan, sikap demokratis siswa kelas X TITL 1 SMK Negeri 3 Singaraja berada pada kategori tinggi.

Siklus II, seluruh siswa sudah terjadi peningkatan kemampuan berpikir kritis siswa sesuai dengan kriteria keberhasilan yang sudah ditentukan. Secara keseluruhan siklus I dan siklus II sudah mengalami peningkatan sesuai dengan kriteria peningkatan kemampuan berpikir kritis maupun sikap demokratis siswa. Kekurangan atau kendala pada siklus I sudah teratasi walaupun masih perlu dilakukan bimbingan untuk membuat siswa meningkatkan cara belajar yang lebih baik lagi dan kemampuan berpikir kritis siswa maupun sikap demokratis siswa.

Berdasarkan observasi awal peneliti lakukan saat proses pembelajaran berlangsung dikelas X TITL 1 SMK Negeri 3 Singaraja, adapun permasalahan yang dialami adalah kurangnya kemampuan berpikir kritis siswa dalam mengikuti pembelajaran dan menaggapi permasalahan yang diberikan pada proses pembelajaran khususnya dalam pembelajaran PKn dan kurangnya sikap demokratis siswa dalam pergaulan di sekolah dan permasalahan yang lebih rinci sudah dipaparkan pada latar belakang penelitian ini. Selain itu kondisi siswa dan keadaan kelas juga mempengaruhi proses pembelajaran disekolah sehingga siswa cendrung tidak mau berpartisipasi dalam pembelajaran jika tidak diberikan semangat atau dukungan dengan cara memberikan poin bagi siswa yang mau bertanya maupun yang menanggapi pertanyaan dari guru selain itu pemilihan model pembelajaran juga penting, karena dengan pemilihan model pembelajaran yang tepat dan menarik akan membuat siswa menjadi semangat dalam mengikuti pembelajaran supaya adanya peningkatan kemampuan berpikir kritis siswa dan sikap demokratis siswa dalam mengikuti proses pembelajaran.

Hasil analisis terhadap proses pelaksanaan pembelajaran dengan menggunakan model pembelajaran Gl untuk meningkatkan kemampuan berpikir kritis siswa menunjukkan bahwa adanya peningkatan kemampuan siswa dalam berpikir kritis. Pemaparan ini tidak terlepas dari hasil yang diperoleh selama melaksanakan evaluasi pada siklus I dan siklus II dan selain itu data menunjukan bahwa adanya peningkatan pada siklus I presentase kemampuan berpikr kritis siswa berada pada angka $71,19 \%$ namun terlihat pada siklus II adanya peningkatan sebanyak $85,36 \%$, baik dari segi kemampuan siswa dalam mengikuti pembelajaran dengan penerapan model pembelajaran Gl.

Hasil analisis terhadap proses pelaksanaan pembelajaran dengan menggunakan model pembelajaran Gl untuk meningkatkan sikap demokratis siswa menunjukkan bahwa adanya peningkatan sikap siswa dalam sikap demokratis siswa. Pemaparan ini tidak terlepas dari hasil yang diperoleh selama melaksanakan evaluasi pada siklus I dan siklus II dan selain itu data menunjukan bahwa adanya peningkatan pada siklus I presentase sikap demokratis siswa berada pada angka $80,45 \%$ namun terlihat pada siklus II adanya peningkatan sebanyak $89,95 \%$, baik dari segi kemampuan siswa dalam mengikuti pembelajaran dengan penerapan model pembelajaran GI.

Berdasarkan hasil penelitian yang telah peneliti lakukan pada siklus I dan siklus II dapat diketahui tingkat sikap demokratis siswa yang sudah mengalami perubahan. Semakin banyak siswa yang berperan aktif mengikuti proses pembelajaran, siswa sudah tidak merasa malu ataupun takut dalam mengemukakan pendapat dan menanggapi permasalahan yang telah diberikan, siswa sudah mampu bertanggung jawab dalam kelompoknya.

Berdasarkan pemaparan diatas, dapat disimpulkan bahwa penerapan model pembelajaran kooperatif tipe GI (Group Investigation) dapat meningkatkan sikap demokratis siswa kelas X TITL 1 SMK Negeri 3 Singaraja. Peningkatan tersebut dapat dilihat dengan adanya peningkatan skor rata - rata sikap demokratis siswa disetiap siklus.

Penelitian ini, disamping memiliki kelebihan namun penelitian ini juga masih memiliki kendala - kendala yang dihadapi dalam proses belajar mengajar. Adapun kendala - kendala yang dihadapi seperti: a) Siswa masih belum terbiasa dengan model pembelajaran kooperatif tipe GI (Group Investigation), karena model pembelajaran ini baru pertama kalinya diterapkan di kelas X TITL 1 SMK Negeri 3 Singaraja. b) Kemampuan siswa mengungkapkan pendapatnya masih relatif kurang, karena hal ini sangat erat kaitannya dengan kemampuan berbahasa lisan dari diri siswa sehingga siswa masih agak kaku dalam menyampaikan pendapat apalagi kemampuan siswa tersebut masih relatif rendah, c) Masih ada beberapa kelompok yang belum bisa menyelesaikan tugas atau kasus yang diberikan dengan adanya batasan waktu, d) Masih ada kelompok yang kemampuan mempresentasikan dan mengklarifikasi hasil investigasi atau diskusi kelompok masih kurang, e) Siswa sulit dalam menyatukan pendapat ketika melakukan investigasi atau diskusi kelompok sehingga belum bisa menyelesaikan tugas tepat waktu dan waktu terbuang sia - sia, f) Pelaksanaan siklus I pada pertemuan pertama peneliti kekurangan 
waktu dalam mengimplementasikan model pembelajaran kooperatif tipe Gl (Group Investigation) sehingga materi pembelajaran tidak diterima secara utuh oleh siswa.

Melihat dari adanya kendala - kendala yang dihadapi selama proses pembelajaran, maka perlu mempertimbangkan upaya - upaya untuk menanggulangi permasalahan yang timbul pada proses pembelajaran tersebut. Adapun upaya yang dilakukan oleh peneliti untuk mengatasi permasalahan tersebut yaitu: a) Peneliti menciptakan proses pembelajaran yang menyenangkan dengan cara memberi semangat kepada siswa untuk lebih aktif lagi dalam mengikuti pembelajaran, b) Mengaktifkan seluruh anggota kelompok dalam mengemukakan pendapat, c) Menekankan pada siswa atau kelompok belajar bahwa dalam setiap langkah dalam kegiatan pembelajaran selalu ada penilaian baik kognitif, afektif dan psikomotor, d) Peneliti mengkaitkan materi pembelajaran dengan kehidupan nyata siswa, e) Peneliti memberikan pertanyaan terkait dengan kehidupan nyata siswa, f) Melakukan bimbingan intensif pada kelompok belajar atau perindividu yang mengalami kesulitan, g) Dan yang terakhir peneliti memberikan reward pada kelompok yang dapat mempresentasikan hasil diskusi dengan baik.

\section{Simpulandan Saran}

Berdasarkan hasil penelitian dan pembahasan yang telah diuraikan pada bab sebelumnya, maka dapat diambil suatu simpulan sebagai berikut: 1) Berdasarkan hasil observasi dan analisis data yang peneliti lakukan, penerapan model pembelajaran kooperatif tipe GI (Group Investigation) dapat meningkatkan kemampuan berpikir kritis siswa kelas X TITL SMK Negeri 3 Singaraja pada mata pelajaran PKn. Hal ini dapat dilihat dari hasil tes kemampuan berpikir kritis siswa pada siklus I dengan jumlah skor keseluruhan 71,19 dan pada siklus II skor kesluruhan menjadi 85,36. 2) Penerapan model pembelajaran kooperatif tipe GI (Group Investigation) dapat meningkatkan sikap demokratis siswa kelas X TITL 1 SMK Negeri 3 Singaraja pada mata pelajaran PKn. Hal ini dapat dilihat dari skor keseluruhan pada siklus I adalah 1.609 dan skor rata - rata sikap demokratis siswa sebesar 80,45 dengan standar deviasi sebesar 2.8, perolehan skor ini termasuk dalam kategori sedang dan pada siklus II skor keseluruhan adalah 1.853 dan skor rata - rata sikap demokratis siswa sebesar 92,65 dengan standar deviasi sebesar 4,5, perolehan skor ini termasuk dalam kategori sedang. Jadi dari siklus I ke siklus II telah terjadi peningkatan skor rata - rata sikap demokratis siswa 12,20\%. 3) Kendala yang dihadapi dalam penerapan model pembelajaran kooperatif tipe Gl (Group Investigation) selama penelitian yaitu, siswa masih belum terbiasa dengan model pembelajaran kooperatif tipe Gl (Group Investigation), kemampuan siswa dalam mengungkapkan pendapat masih kurang, masih ada beberapa kelompok yang belum bisa menyelesaikan tugas sesuai waktu, adanya kemampuan berbeda - beda dalam memahami materi pembelajaran dan kurangnya pemanfaatn waktu dalam dalam pelaksanaan siklus I dalam pertemuan pertama.

4) Alternatif pemecahan yang peneliti gunakan untuk mengatasi kendala - kenadala tersebut yaitu, Peneliti menciptakan proses pembelajaran yang menyenangkan dengan cara memberi semangat kepada siswa untuk lebih aktif lagi dalam mengikuti pembelajaran, Mengaktifkan seluruh anggota kelompok dalam mengemukakan pendapat, Menekankan pada siswa atau kelompok belajar bahwa dalam setiap langkah dalam kegiatan pembelajaran selalu ada penilaian baik kognitif, afektif dan psikomotor, Peneliti mengkaitkan materi pembelajaran dengan kehidupan nyata siswa, Peneliti memberikan pertanyaan terkait dengan kehidupan nyata siswa, Melakukan bimbingan intensif pada kelompok belajar atau perindividu yang mengalami kesulitan Dan yang terakhir peneliti memberikan reward pada kelompok yang dapat mempresentasikan hasil diskusi dengan baik.

Berdasarkan Kesimpulan diatas, dapat disampaikan saran-saran sebagai berikut : 1) Disarankan kepada siswa, dengan penerapan model pembelajaran kooperatif tipe GI (Group Investigation) ini dapat dijadikan sebagai strategi pembelajaran yang menekankan pada konsentrasi siswa, dan siswa juga dapat tertantang serta dapat menyenangkan bagi sisa dan dapat menciptakan penguasaan siswa terhadap konsep - konsep serta dapat meningkatkan konsentrasi belajar siswa. 2) Disarankan kepada PKn hasil penelitian ini dapat menambah wawasan mereka terkait penggunaan media pembelajaran serta dapat dijadikan suatu solusi dalam melaksanakan kegiatan pembelajaran sehingga dapat meningkatkan kemampuan berpikir kritis siswa dan sikap demokratis siswa serta dapat menerapkan penerapan model pembelajaran kooperatif tipe GI (Group Investigation) pada pembelajaran PKn sebagai suatu alternatif pembelajaran. 3) Disarankan kepada sekolah penerapan model pembelajaran kooperatif tipe Gl (Group Investigation) dapat dijadikan sebagai alternatif bagi perbaikan kualitas pembelajaran. 4) Kepada peneliti lain yang berminat untuk mengadakan penelitian 
lebih lanjut mengenai penerapan model pembelajaran kooperatif tipe GI (Group Investigation) dalam mata pelajaran PKn khususnya maupun bidang ilmu lainnya yang sesuai, agar penelitian ini dapat dijadikan acuan ataupun refrensi demi ketuntasan penelitian selanjutnya dan memperhatikan kendala - kendala yang peneliti alami sebagai bahan pertimbangan untuk perbaikan dan menyempurnakan pelaksanaan peneliti.

\section{DaftarPustaka}

Adora, Nelia M. 2014. Group Investigation in Teaching Elementary Science. International Journal of Humanities and Management Sciences, 2 (3): 146-147.

Akly, Nur, Andi Halimah. 2015. Efektivitas Penerapan Model Pembelajaran Kooperatif Tipe Group Investigation (Gl) terhadap Hasil Belajar Fisika. Jurnal Pendidikan Fisika Vol. 3 No. 1 Hal.52-57. Tersedia Pada : http://journal.uinalauddin.ac.id/index.php/PendidikanFisika/article/view/4105.

Arikunto, Suharsimi. 1918. Prosedur Penelitian, suatu pendekatan praktek. Jakarta : Renika Cipta.

Arisinta, Renika, Bayu Hendro Wicaksono, Ima Wahyu Putri Utami. 2017. Pengembangan Group Investigation dengan Permainan "Aku Seorang Detektif" Kelas IV SD Muhammadiyah 1 Malang. Jurnal Pemikiran dan Pengembangan SD Volume 5, Nomor 2 Hal. 732-742. Tersedia Pada http://ejournal.umm.ac.id/index.php/jp2sd/article/view/4822/4956.

Artini, Marungkil Pasaribu, dan Sarjan. M. Husain. 2015. Penerapan Model Pembelajaran Kooperatif Tipe Group Investigation untuk Meningkatkan Aktivitas dan Hasil Belajar IPA Pada Siswa Kelas VI SD Inpres 1 Tondo. e-Jurnal Mitra Sains, Volume 3 Nomor 1, Hal. 45-52. Tersedia Pada http://jurnal.untad.ac.id/jurnal/index.php/MitraSains/article/view/4135.

Arya Sunu, I Gusti Ketut.2015. Manajemen kelas; aplikasi dalam proses pembelajaran di Pendidikan Formal. Yogyakarta: Media Akademi.

Depdiknas, 1990. Kamus Besar Bahasa Indonesia. Jakarta: Balai Pustaka.

Erwin, Muhamad. 2010, Pendidikan Kewarganegaraan Republik Indonesia. Bandung:PT Refika Aditama.

Halpen. 1996. Memahami Berpikir Kritis. Bandung: Artikel Pendidikan.

Hamalik, Oemar. 2005. Proses belajar mengajar. Jakarta: PT Bumi Aksara.

Harahap, Ria Astri, Derlina. 2017. Pembelajaran Kooperatif Tipe Group Investigation (GI) dengan Metode Know-Want-Learn (KWL): Dampak terhadap Hasil Belajar Fluida Dinamis. Jurnal IImiah Pendidikan Fisika Al-BiRuNi Vol. 06 No. 2 Hal. 149-158. Tersedia Pada : http://ejournal.radenintan.ac.id/index.php/al-biruni/article/view/1369/0.

Iskandar. 2008. Metodelogi Penelitian dan sosial (Kuantitatif dan Kualitatif. Jakarta: PT Bumi Aksara.

Ita Damayanti, Ni Kadek. 2017. Implementasi Model Pembelajaran Talking Stick untuk Meningkatkan Motivasi, Aktivitas dan Hasil Belajar Siswa Kelas VIII B8 SMP Negeri 6 Singaraja dalam Pembelajaran Pendidikan Kewarganegaraan Tahun Pelajaran 2016/2017. (Joernal).

Lasmawan, W.2010. Menelisik Pendidikan IPS dalam Persefektif Kontekstual Empiris. Singaraja: Medakom Indonesia Press Bali. 
TSCJ, Vol 2 No 1, Tahun 2019

p-ISSN : 2615-4692 e-ISSN : 2615-6105

Suariana, I Made. 2017. Penerapan Model Pembelajaran Kooperatif Tipe GI (Group Investigasi) Untuk Meningkatkan Aktivitas, Sikap Demokratis dan Prestasi Belajar PKn Pada Siswa Kelas XI Busana SMK Negeri 2 Singaraja. Skripsi (tidak diterbitkan).

Sumertha, I Gede. 2019. Penerapan Model Pembelajaran Kooperatif Tipe Group Investigation (GI) untuk Meningkatkan Hasil Belajar IPA Siswa. Jurnal Pedagogi dan Pembelajaran Vol 2 No 2 Hal. 195-202. Tersedia Pada : https://ejournal.undiksha.ac.id/index.php/JP2/article/view/17908/10706.

Pitoyo, Andri, Herman J. Waluyo, Sarwiji Suwandi, \& Andayani. 2014. The Effect of Group Investigation Learning Model, Accelerated Learning Team and Role Playing on Elementary School Student' Writing Skills Viewed from Cognitive Style. Journal of Education and Practice, 5 (1): 21-29.

Trianto. 2009. Mendesain Model Pembelajaran Inovatif - Progresif. Jakarta: Kencana Pernaa Media Group.

Undang - Undang Republik Indonesia No. 20 Tahnun 2003 Tentang Slstem Pendidikan Nasional 2003. Jakarta : Depdiknas. 